\title{
PENGARUH PENDAPATAN USAHA PRODUKTIF ISTRI NELAYAN TERHADAP PENDAPATAN KELUARGA NELAYAN DI KECAMATAN BANGGAE KABUPATEN MAJENE
}

\author{
Oleh \\ Zulkifli \\ Program Studi Perbankan Syariah - Institut Agama Islam Negeri (IAIN) Bone \\ nalling_jnp@ymail.com \\ DOI Artikel : https://doi.org/10.34308/eqien.v7i1.105
}

\section{Article Info}

Article History :

Received $10 \mathrm{Feb}-2020$

Accepted $20 \mathrm{Feb}-2020$

Available Online $28 \mathrm{Feb}-2020$

\begin{abstract}
The purpose of this study was to study the productive income of fishermen towards the income of fishermen families in Banggae District, Majene Regency. The data analysis technique used in this study is a simple linear regression test.research results results of management of factors that may be obtained by many positives and high functions for spending women's families in bangung subdistrict, majene regency.
\end{abstract}

Keyword :

Income, Productive Business,

Family, Family, Fisherme

\section{PENDAHULUAN}

Kabupaten Majene adalah salah satu dari 5 Kabupaten dalam wilayah Propinsi Sulawesi Barat dengan panjang pantai 125 $\mathrm{Km}$ yang terlatak di pesisir pantai Sulawesi Barat memanjang dari Selatan ke Utara dengan luas 947,84 Km. Kabupaten Majene terdiri terdiri dari 8 Kecamatan yaitu Banggae, Banggae Timur, Pamboang, Sendana, Tammero'do Sendana, Tubo Sendana, Malunda dan Ulumanda, yang meliputi 40 desa dan kelurahan. Ibukota Kabupaten Majene terletak di Kecamatan Banggae dengan luas perkotaan $5.515 \mathrm{~km}$, yang berada di posisi selatan Kabupaten Majene, dengan jam tempuh sekitar 3 jam sampai 4 jam dari ibukota Sulawesi Barat (Mamuju) yaitu $\pm 142 \mathrm{~km}$.

Kabupaten Majene berada pada ketinggian yang bervariasi antara $0-1.600$ meter di atas permukaan laut, Daerah ini mempunyai topografi yang sebagian besar merupakan lahan perbukitan dengan vegetasi yang mulai rusak akibat adanya pembukaan hutan menjadi sawah ladang (30\% dari luas total 94,784 ha). Sisa dari lahan yang ada berupa daratan aluvial pantai dan batuan gamping (70\%) sehingga potensi aliran sungai gunung dan mata air terbatas, apalagi di musim kemarau.

Sebagai salah satu daerah yang berada dipesisir pantai maka kabupaten Majene memiliki potensi perikanan yang cukup besar. Komoditas perikanan laut di Kabupaten Majene beraneka ragam, berdasarkan data dari Dinas Kelautan dan Perikanan Kabupaten Majene tahun 2017 produksi ikan tuna dengan rata-rata 782 ton, ikan cakalang 694 ton, tongkol 1.025 ton, ikan layang 621 ton, dan ikan terbang 730 ton. Ikan laut ini sebagian besar oleh nelayan dijual dalam bentuk mentah dan ada juga dalam bentuk yang sudah di olah menjadi bahan makanan. Untuk pemasaran pada umumnya berada dikabupaten majene sendiri maupun beberapa kabupaten lainnya di Sulawesi Barat seperti Polewali, Mamasa, Mamuju, Mamuju tengah, dan Mamuju Utara.

Desa Cilallang dan desa Tanangan Kecamatan Banggae Kabupaten Majene merupakan salah satu wilayah dengan jumlah tangkapan ikan yang cukup banyak 
di Kabupaten Majene, sebagian besar penduduknya adalah nelayan tradisional dan buruh nelayan yang tidak mempunyai kapal dan alat tangkap sendiri. Pendapatan buruh nelayan biasanya sangat kecil dan tidak cukup untuk memenuhi kebutuhan seharihari. Keadaan ini memaksa istri-istri nelayan mencari alternatif usaha untuk menambah pendapatan keluarga melalui usaha produktif yang dapat menambah penghasilan keluarga.

Istri nelayan di Desa Cilallang dan desa Tanangan Kecamatan Banggae Kabupaten Majene ikut serta dalam usaha perikanan dan non perikanan dengan berbagai motivasi, sebagian besar istri nelayan melakukan kegiatan produksi untuk memberikan tambahan nafkah dengan curahan waktu yang cukup besar. Ikut sertanya istri nelayan dalam kegiatan/usaha produktif untuk menambah penghasilan keluarga.

\section{KERANGKA PEMIKIRAN PENGAMBANGAN HIPOTESIS Konsep Pendapatan}

Menurut Horngren,et al. (2009;301), penjualan merupakan nama lain dari pendapatan yang merupakan jumlah yang didapat dari hasil penjualan barang dagang yang dimilikinya sebelum dikurangi dengan beban-beban dan dilakukannya secara berjangka. Sedangkan menurut adji dkk (2007:165) bahwa pendapatan atau income adalah uang yang diterima oleh seseorang dan perusahaan dalam bentuk gaji, upah, sewa, bunga dan laba termasuk juga beragam tunjangan seperti kesehatan dan pensiun.

Menurut soekartawi (2006; 54-58) pendapatan adalah selisih antara penerimaan dan semua biaya dengan rumus sebagai berikut :

$$
\begin{array}{cl}
\mathrm{P}_{\mathrm{d}}=\text { TR }-\mathrm{TC} & \\
\text { Dimana : } & \\
\text { TR } & =\text { Y.P } \mathrm{P}_{\mathrm{y}} \\
\mathrm{TC} & =\mathrm{FC}+\mathrm{VC} \\
\text { Keterangan } & \\
\mathrm{P}_{\mathrm{d}} & =\text { Pendapatan } \\
\mathrm{TR} & =\text { Total Penerimaan } \\
\mathrm{TC} & =\text { Total Biaya } \\
\mathrm{Y} & =\text { Jumlah Produk } \\
\mathrm{P}_{\mathrm{y}} & =\text { Harga Y } \\
\mathrm{FC} & =\text { Biaya Tetap } \\
\mathrm{VC} & =\text { Biaya Tidak Tetap }
\end{array}
$$

Usaha produktif istri nelayan di Kecamatan Banggae Kabupaten Majene yaitu aktif dalam kegiatan penjualan ikan segar, dan pengolahan ikan menjadi bahan makanan seperti ikan asin, abon ikan, bakso ikan dan nugget ikan.

Berdasarkan latar belakang yang telah diuraikan diatas maka penulis tertarik melakukan penelitian dengan judul Pengaruh Pendapatan Usaha Produktif Istri Nelayan Terhadap Pendapatan Keluarga Nelayan Di Kecamatan Banggae Kabupaten Majene.

\section{Rumusan Masalah}

Rumusan masalah dalam penelitian ini yaitu bagaimana pengaruh pendapatan usaha produktif istri nelayan terhadap pendapatan keluarga nelayan di Kecamatan Banggae Kabupaten Majene ?

\section{Pendapatan Perseorangan}

Pendapatan perseorangan atau pribadi adalah semua pendapatan atau penghasilan yang diperoleh seseorang dalam kegiatan ekonomi dalam waktu tertentu. Pada umumnya Pendapatan Pribadi atau Personal Income dapat dibedakan dalam:

a. Pendapatan Nominal

Pendapatan nominal adalah pendapatan yang dinyatakan dalam bentuk sejumlah uang

b. Pendapatan Rill ( nyata)

Pendapatan rill adalah pendapatan sejumlah barang dan jasa yang dapat dibeli dengan pendapatan nominal.

Adapun macam-macam pendapatan seseorang terdiri dari :

1) Sewa Tanah adalah pendapatan yang diterima oleh pemilik tanah dalam jangka waktu tertentu.

2) Upah adalah sejumlah uang, barang dan jasa yang diterima seseorang dalam jangka waktu tertentu atas pemakaian tenaga atau pemikiran.

3) Pendapatan modal adalah pendapatan seseorang dari modal yang dimiliki.

4) Pendapatan pengusaha adalah pendapatan yang diterima oleh para pengusaha. Pendapatan ini sering kali merupakan kumpulan dari beberapa pendapatan. 
Tinggi rendahnya pendapatan seseorang ditentukan oleh :

a) Kecakapan dalam kegiatan bekerja

b) Keahlian dan keuletan

c) Kesempatan bekerja yang tersedia

d) Banyak sedikitnya modal yang digunakan

e) Kekayaan yang dimilikinya

\section{Sumber Pendapatan}

Menurut Bastian (2011) pendapatan atau income dari seorang masyarakat adalah hasil penjualannya dari faktorfaktor produksi yang dimilikinya kepada sektor produksi. Sektor produksi ini membeli faktor-faktor produksi tersebut untuk digunakan sebagai input proses produksi dengan harga yang berlaku dipasar faktor produksi. Harga faktor produksi dipasar (seperti halnya juga untuk barang-barang dipasar barang) ditentukan oleh tarik menarik, antara penawaran dan permintaan Secara singkat, income dari seorang warga masyarakat ditentukan oleh

a) Jumlah faktor-faktor produksi yang ia miliki yang bersumber pada hasil-hasil tabungannya ditahuntahun yang lalu, atau warisan / pemberian.

b) Harga per unit dari masing-masing faktor produksi. Harga-harga ini ditentukan oleh kekuatan

\section{METODE PENELITIAN}

\section{Lokasi Penelitian}

Penelitian ini dilaksanakan di

Kecamatan Banggae Kabupaten Majene. Pemilihan lokasi ini dengan beberapa pertimbangan peneliti, yaitu rumah tangga nelayan dengan jumlah terbesar di Kabupaten Majene berada di Kecamatan Banggae.

\section{Populasi dan sampel Populasi}

Populasi dalam penelitian ini adalah seluruh istri nelayan di Kecamatan Banggae Kabupaten Majene yang berjumlah 1341 orang.

\section{Sampel}

Sampel adalah bagian dari jumlah dan karakteristik yang dimiliki oleh populasi tersebut. Bila populasi besar, dan peneliti tidak mungkin mempelajari semua yang ada pada populasi. Sampel adalah pengambilan sebagian objek untuk diselidiki yang akan mewakili populasi (Sugiyono,2012) penawaran dan permintaan dipasar faktor produksi.

c) Siklus Aliran Pendapatan (Circular Flow)

Siklus aliran pendapatan (Circular Flow) adalah sebuah model yang menggambarkan bagaimana interakasi antara pelaku ekonomi menghasilkan pendapatan yang digunakan sebagai pengeluaran dalam upaya memaksimalkan nilai kegunaan (utility) masing-masing pelaku ekonomi. Model circular flow membagi perekonomian menjadi beberapa sektor yaitu :

1) Sektor Rumah Tangga (Households Sector), yang terdiri atas sekumpulan individu yang dianggap homogeny dan identik.

2) Sektor Perusahaan (Firms Sector), yang terdiri atas sekumpulan perusahaan yang memproduksi barang dan jasa.

3) Sektor Pemerintah (Government Sector), yang memiliki kewenangan politik untuk mengatur kegiatan masyarakat dan perusahaan.

4) Sektor Luar Negeri (Foreign Sector), yaitu sektor perekonomian dunia, dimana perekonomian melakukan transaksi ekspor -impor.

Teknik penarikan sampel dalam penelitian ini adalah menggunakan rumus Slovin berikut:

$$
\begin{aligned}
& n=\frac{n}{n \cdot d^{2}+1} \\
& n=\frac{1341}{1341.0 .10^{2}+1} \\
& n=93,06 \text { dibulatkan menjadi } 93
\end{aligned}
$$

\section{Teknik Analisis Data \\ Uji Koefisien Regresi}

Untuk mengetahui pengaruh pendapatan usaha produktif istri nelayan terhadap pendapatan keluarga nelayan di Kecamatan Banggae Kabupaten Majene dilakukan uji regresi linear sederhana. Model penelitian yang digunakan dalam penelitian ini adalah :

$$
\mathbf{Y}=\boldsymbol{\beta}_{\mathbf{0}}+\boldsymbol{\beta}_{\mathbf{1}} \mathbf{X}+\mathbf{e}
$$


Keterangan :

$\mathrm{Y}=$ Pendapatan Keluarga Nelayan

$\mathrm{X}_{1} \quad=$ Pendapatan Usaha Produktif Istri Nelayan

\section{HASIL PENELITIAN DAN \\ PEMBAHASAN}

Hasil dan Pembahasan

Pengaruh Pendapatan Istri Nelayan Terhadap Pendapatan Keluarga Nelayan di Kecamatan Banggae Kabupaten Majene

Berdasarkan hasil olah data, didapatkan persamaan dalam penelitian ini menjadi :

$Y=718466,145+1,323 X+\varepsilon$

1. Nilai costanta sebesar $718.466,145$

Jika tidak ada perubahan pada nilai variabel Pendapatan istri nelayan maka Pendapatan keluarga nelayan sebesar 718.466,145

2. Nilai koefisien regresi Pendapatan keluarga nelayan sebesar 1,323

Nilai koefisien regresi Pendapatan istri nelayan sebesar 1,323 menunjukkan

\section{KESIMPULAN}

Kesimpulan dalam penelitian ini yaitu pendapatan usaha produktif istri nelayan

\section{DAFTAR PUSTAKA}

Suharsimi, A. (2006). Prosedur penelitian suatu pendekatan praktik. Jakarta: Rineka Cipta.

Widarjono, A. (2013). Ekonometrika: Pengantar dan aplikasinya, Ekonosia, Jakarta.

Djuwita, D. (2015). Peran Perempuan Masyarakat Pesisir dalam Meningkatkan Pendapatan Keluarga Nelayan di Desa Mertasinga. AlAmwal Jurnal Kajian Ekonomi dan Perbankan Syariah, 7(2).

Hutapea, R., Kohar, A., \& Rosyid, A. (2012). Peranan Wanita Nelayan (Istri Nelayan) Jaring Insang dalam Meningkatkan Pendapatan Keluarga di Desa Bejalen, Perairan Rawa Pening,

$$
\begin{array}{ll}
\beta_{0} & =\text { Intercept } / \text { Konstanta } \\
\beta_{1} & =\text { Parameter/koefisien regresi } \\
\mathrm{e} & =\text { Error terms }
\end{array}
$$

bahwa jika Pendapatan usaha produktif istri nelayan naik sebesar 1 maka Pendapatan keluarga nelayan akan naik sebesar 1,323. Dan sebaliknya Pendapatan usaha produktif istri nelayan turun sebesar 1 maka Pendapatan keluarga nelayan akan turun sebesar 1,323. Sehingga dapat disimpulkan bahwa Pendapatan usaha produktif istri nelayan berpengaruh positif terhadap pendapatan keluarga nelayan .

3. Nilai signifikansi sebesar 0,000

Nilai signifikansi sebesar 0,000 menunjukkan bahwa Pendapatan usaha produktif istri nelayan berpengaruh signifikan terhadap Pendapatan keluarga nelayan di Kecamatan Banggae Kabupaten Majene

berpengaruh positif dan signifikan terhadap Pendapatan keluarga nelayan di Kecamatan Banggae Kabupaten Majene

Kecamatan Ambarawa, Kabupaten Semarang. Journal of Fisheries Resources Utilization Management and Technology, 1(1), 1-10.

Alma, B. (2009). Metode \& Teknik Menyusun Proposal Penelitian. Bandung: Alfabeta.

Rohmiati Amini (2013) Analisis Dampak Pemberdayaan Wanita Nelayan Melalui Program Usaha Garam Rakyat (Pugar) Terhadap Kondisi Ekonomi Keluarga Nelayan Di Kabupaten Lombok Barat. Jurnal. Gane Swara Vol. 7 No.2

Singarimbun, M., \& Effendi, S. (2019). Metode penelitian survai.

Sugiyono, P. D. (2008). Metode penelitian kuantitatif dan kualitatif dan R\&D. Bandung (ID): Alfabeta. 